\title{
Cadaveric Study of The Anatomical Variations of The Accessory Pancreatic Duct
}

\author{
Sunjida Shahriah ${ }^{1}$,Abu Sadat Mohammad Nurunnabi ${ }^{2}$, Fatema Johora ${ }^{3}$, Dilruba Siddiqua ${ }^{4}$, \\ Shamim Ara ${ }^{5}$
}

\begin{abstract}
Background: The accessory pancreatic duct enters the duodenum at the minor duodenal papilla, developmentally draining the dorsal pancreatic bud; however, it is smaller and less constant than the main pancreatic duct and undergoes varying degrees of atrophy at the duodenal end. Objective: The objective of this study was to see the variations in course, opening and communication pattern of the accessory pancreatic duct in different age-groups in a Bangladeshi population. Methods: This crosssectional, descriptive study was done was done in the Department of Anatomy, Dhaka Medical College, Dhaka, from August 2005 to December 2006, based on collection and dissection of 75 postmortem male human pancreas. The collected samples were divided into seven age groups: 10-19 years, 20-29 years, 30-39 years, 40-49 years, 50-59 years), 60-69 years and( $\mathrm{e}^{\wedge} 70$ years. However, 65 samples were taken for final observation. Results: The accessory pancreatic duct was found in $27.69 \%$ specimens. Straight course was found in 50\% specimen, while spindle course in $27.78 \%$ and cudgel course in $22.22 \%$ specimens were observed. In only $4(6.15 \%)$ specimens, the accessory pancreatic duct communicates with the common bile duct, while in $11(16.93 \%)$ specimens, the accessory pancreatic duct communicates with the main pancreatic duct. $12(66.67 \%)$ accessory pancreatic ducts opened into the minor duodenal papilla, while $5(27.78 \%)$ into the major duodenal papilla and $1(5.55 \%)$ into the $3^{\text {rd }}$ duodenal papilla. Conclusion: Several variations were observed in accessory pancreatic duct pattern in terms of their course, opening and communications. However, no significant differences were evident in any parameter among the age groups. Here, females were excluded due to less availability of the female cadaveric pancreas during study period.
\end{abstract}

Key words: Pancreas, pancreaticobiliary ductal system, main pancreatic duct, accessory pancreatic duct.

Bangladesh Soc Physiol. 2014, December; 9(2): 83-88

For Authors Affiliation, see end of text.

http://www.banglajol.info/index.php/JBSP

\section{Introduction}

$\mathbf{T}$

he accessory pancreatic duct is the main drainage duct of the dorsal pancreatic bud in the embryo, entering the duodenum at the minor duodenal papilla ${ }^{1-2}$. The accessory pancreatic duct is the smaller and less constant pancreatic duct in comparison with the main pancreatic duct ${ }^{3}$; as development progresses, this duct of the dorsal bud undergoes varying degrees of atrophy at the duodenal end ${ }^{2-3}$. A clear

Received December 2014; Accepted April 2014 understanding of the pancreaticobiliary ductal anatomy and its possible variation is essential for any surgeon operating in that region. Presence of acute bends and loops in course of the pancreatic duct are the site of stasis of the pancreatic juice and the formation of pancreatic calculi ${ }^{3}$ and wide variation in the direction of course makes it difficult to remove the calculi within the duct and difficulties in endoscopic retrograde cholangiopancreatiogram (ERCP) 
canulation $^{4}$. Prolonged stagnation of pancreatic juice in ductal system causes the erosion of ductal lumen followed by extravasations in the neighbouring parenchyma and rapid autolysis leading to acute pancreatites ${ }^{3-5}$. Duodenal communication with pancreatic duct may lead to very small worm or rarely small seed impaction in the ductal opening ${ }^{4-5}$. Numerous variations in the ducts can be understood from their complicated development. All of the variations in the ductal system are secondary to differences in embryologic development and can be of clinical significance ${ }^{6-8}$. Moreover, in pancreas divisum, resulted from an incomplete fusion of the ventral pancreatic duct with the dorsal duct during fetal development, is present in $5 \%$ of patients ${ }^{7}$. In this anomaly, the minor pancreatic duct drains the entire pancreas; inadequacy of this pattern of drainage can result in chronic pain ${ }^{7-8}$. A patent accessory pancreatic duct may prevent acute pancreatitis by lowering the pressure in the main pancreatic duct. In cases of pancreaticobiliary maljunction with a patent accessory pancreatic duct, the incidence of carcinogenesis of the bile duct might be lower, as the reflux of the pancreatic juice to the bile duct might be reduced by the flow of the pancreatic juice into the duodenum through the accessory pancreatic duct ${ }^{2,6-10}$. Several studies have been done on different populations in different countries; however; no study has been found till to date on Bangladeshi people. Hence, this study has been proposed to explore the anatomical variations in the accessory pancreatic duct in cadaveric specimens of a Bangladeshi population.

\section{Methods}

A cross-sectional, descriptive study was done in the Department of Anatomy, Dhaka Medical College, Dhaka, from August 2005 to December 2006 , based on collection of 75 postmortem male human pancreas aging from 10 to 76 years. The collected samples were divided into seven age groups: 10-19 years, 20-29 years, 30-39 years,4049 years, $50-59$ years, $60-69$ years and e" 70 years, for convenient description of the variations in different age-groups according to Varley et al. ${ }^{11}$.

The samples were free from any apparent signs of decomposition, any injury in pancreas, death due to poisoning, death due to known pancreatic disease, and untraceable accessory pancreatic duct during dissection. The present study was approved by the Ethical Review Committee of Dhaka Medical College, Dhaka.

Collection and dissection of the specimens: The specimen with related structures such as duodenum was taken en block with a sample number. It was initially washed with the free flowing tap water in a basin to wash away the blood and intestinal soiling. Then it was kept under the linear flow of running tap water for about 15 minutes to get rid of unwanted bad odors. Surrounding fat and unwanted tissues were removed to expose the pancreas and its related structures. Then the specimen was taken on a metallic tray and the site of entry of the main pancreatic duct with or without association of common bile duct was identified by palpation ${ }^{12}$. With the help of blunt end of Birds Parker knife (blade size:3) adjoining fascia between the cshaped curvature of duodenum and pancreas was separated and excised after preserving the external part of the main pancreatic duct, the minor/accessory pancreatic duct, if present, and the common bile duct. Then following the main pancreatic duct; on the posterior surface of the pancreas, an incision into the gland parallel and close to the superior and inferior margins of the body was given. The lobules were picked away in piecemeal between the cuts to expose the greyish-white duct. The duct was traced in both directions taking care to expose the accessory duct and its tributaries in the head of the pancreas. Both ducts were followed to the duodenum and their openings were identified on the internal surface of the duodenum ${ }^{13}$. Ampulla was followed as guide to separate pancreatic tissues reveal the main pancreatic duct ${ }^{14}$. From the head end by piecemeal dissection the course 
of the main pancreatic duct was followed till the extreme tail end. Common bile duct's location on the posterior surface of the pancreas was identified, if it was submerged in the pancreatic soft tissue, then the common bile duct was dissected out ${ }^{12}$. The total ductal system including main pancreatic duct, accessory pancreatic duct, and common bile duct were completely dissected keeping the communication with the duodenum (figure 1).

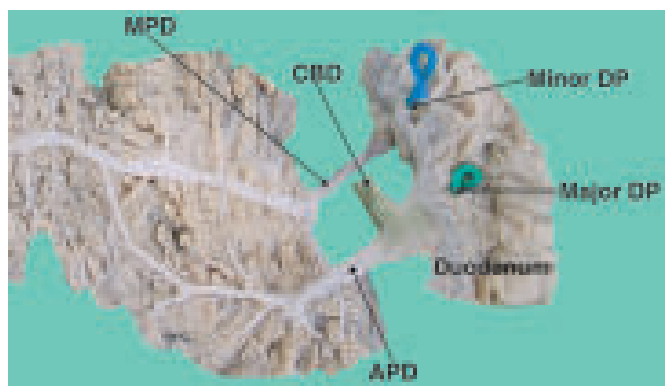

Figure 1: Specimen of block dissection of pancreaticobiliary ductal pattern, taken from 2029 years age group. MPD = Main Pancreatic Duct, $\mathrm{APD}=$ Accessory Pancreatic Duct, $\mathrm{CBD}=$ Common Bile Duct, DP = Duodenal Papilla.

Contrast $x$-ray procedure and observation: Besides, diluted aqueous solution of barium sulphate was infused into the duodenal opening in the fresh sample and x-ray was taken. Here, presence of the accessory pancreatic duct was observed along with its course ${ }^{11}$. The communication of accessory pancreatic duct with common bile duct was observed within and outside of the pancreas. Number of communications alone with the drainage pattern was noted ${ }^{15}$. Again, communication between main pancreatic duct and accessory pancreatic duct was observed both within and outside the pancreas. Number of communications alone with the drainage pattern was noted ${ }^{14}$. Besides, mode of opening of the accessory pancreatic duct was observed $^{16}$ (figure 2).

All data were collected, compiled and presented in frequency percent. Data were analysed by chi square test. Appropriate statistical analyses were done by using SPSS version 11.0.

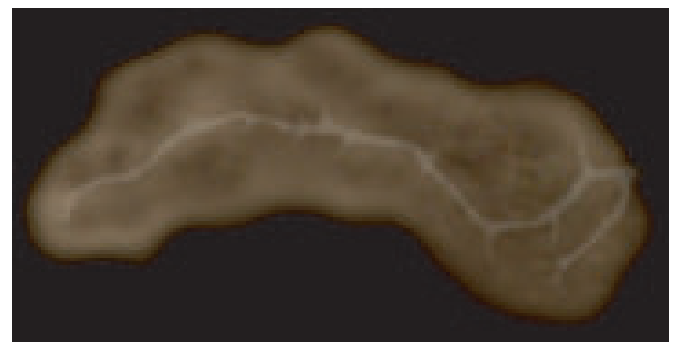

Figure 2: Barium $x$-ray of the pancreas showing main pancreatic duct and accessory pancreatic duct, taken from 40-49 years group.

\section{Results}

In the present study, among 65 finally observed specimens, the accessory pancreatic duct was found in $18(27.69 \%)$. Table-I shows the presence of the accessory pancreatic duct in different age groups. In $>70$ years age group, accessory pancreatic duct was found in $60 \%$ specimens and on the other hand, in age group 10-19 years, it was only $16.67 \%$. There were 3 variations observed in course of the accessory pancreatic duct. Among those, straight course was found in $50 \%$ specimens, while spindle course in $27.78 \%$ and cudgel course in $22.22 \%$ specimens were observed (Table II).

Table I : Accessory pancreatic duct (APD) in different age group

\begin{tabular}{lcc}
\hline Age Group & APD present no. & $\%$ \\
\hline $10-19$ years $(n=6)$ & 1 & 16.67 \\
$20-29$ years $(n=17)$ & 5 & 29.41 \\
$30-39$ years $(n=14)$ & 3 & 21.41 \\
$40-49$ years $(n=11)$ & 3 & 27.27 \\
$50-59$ years $(n=7)$ & 1 & 14.29 \\
$60-69$ years $(n=5)$ & 2 & 40 \\
$>70$ years $(n=5)$ & 3 & 60 \\
\hline
\end{tabular}


Among those specimens, no communication between the common bile duct with accessory pancreatic duct was observed in 14 (21.54\%). Single and quadruple communications between the common bile duct with accessory pancreatic duct was present only in 1 specimen each in group B. Triple communication between the common bile duct with main pancreatic duct was observed in 1 specimen each in 20-29 years group and (table III).

In only $11(16.93 \%)$ specimens, the accessory pancreatic duct communicates with the main pancreatic duct. Single communication was found in 1 specimen each in group20-29 years and 4049years. Double connections were found in 1 specimen each in group 20-29 years, 40-49 years and e"70, while triple connections were found in 1 specimen each in group 20-29 years,30-39 years and e"70. Moreover, quadruple communications were evident in 1 case each in group 20-29 years, 60-69 years and e"70 (table IV).

Finally, it was also observed that 12 (66.67\%) accessory pancreatic ducts opened into the minor duodenal papilla, while $5(27.78 \%)$ into the major duodenal papilla and only 1 (5.55\%) accessory pancreatic duct opened into the $3^{\text {rd }}$ duodenal papilla. However, in the present study, no significant differences were evident in any parameter among the age groups.

Table II: Course of the accessory pancreatic duct (APD) in different age group

\begin{tabular}{|c|c|c|c|c|c|c|c|c|}
\hline Type & $\begin{array}{c}\text { Number } \\
(\%)\end{array}$ & $\begin{array}{l}10-19 \\
\text { years } \\
(n=6)\end{array}$ & $\begin{array}{l}20-29 \\
\text { years } \\
(n=17)\end{array}$ & $\begin{array}{l}30-39 \\
\text { years } \\
(\mathrm{n}=14)\end{array}$ & $\begin{array}{c}40-49 \\
\text { years } \\
(n=11)(n=7)\end{array}$ & $\begin{array}{l}50-59 \\
\text { years } \\
(n=5)\end{array}$ & $\begin{array}{l}60-69 \\
\text { years } \\
(n=5)\end{array}$ & $\begin{array}{l}>70 \\
\text { years }\end{array}$ \\
\hline Straight & $9(50)$ & 1 & 2 & 1 & 1 & 1 & 1 & 2 \\
\hline Spindle & $5(27.78)$ & - & 1 & 2 & 1 & - & - & 1 \\
\hline Cudgel & $4(22.22)$ & - & 2 & - & 1 & - & 1 & - \\
\hline
\end{tabular}

Table III: Communication between the accessory pancreatic duct and the common bile duct in different age group

\begin{tabular}{lccccc}
\hline Group & No & \multicolumn{3}{c}{ Communication } \\
& communication & & & \\
& No. $(\%)$ & Single & Double & Triple & Quadruple \\
& & No. $(\%)$ & No. $(\%)$ & No. $(\%)$ & No. $(\%)$ \\
\hline $10-19$ years $(n=6)$ & $1(16.67)$ & - & - & - & - \\
$20-29$ years $(n=17)$ & $2(11.76)$ & $1(5.88)$ & - & $1(5.88)$ & $1(5.88)$ \\
$30-39$ years $(n=14)$ & $2(14.29)$ & - & - & $1(7.14)$ & - \\
$40-49$ years $(n=11)$ & $3(27.27)$ & - & - & - & - \\
$50-59$ years $(n=7)$ & $1(14.29)$ & - & - & - & - \\
$60-69$ years $(n=5)$ & $2(40.00)$ & - & - & - & - \\
$>70$ years $(n=5)$ & $3(60.00)$ & - & - & - \\
\hline
\end{tabular}


Table IV: Communication between accessory pancreatic duct (APD) and main pancreatic duct (MPD) in different age group

\begin{tabular}{lccccc}
\hline Group & $\begin{array}{c}\text { No } \\
\text { communication } \\
(\%)\end{array}$ & $\begin{array}{c}\text { Single } \\
(\%)\end{array}$ & $\begin{array}{c}\text { Double } \\
(\%)\end{array}$ & $\begin{array}{c}\text { Triple } \\
(\%)\end{array}$ & $\begin{array}{c}\text { Quadruple } \\
(\%)\end{array}$ \\
\hline 10-19 years $(\mathrm{n}=6)$ & $1(16.67)$ & - & - & - & - \\
20-29 years $(\mathrm{n}=17)$ & $1(5.88)$ & $1(5.88)$ & $1(5.88)$ & $1(5.88)$ & $1(5.88)$ \\
30-39 years $(\mathrm{n}=14)$ & $2(14.29)$ & - & - & $1(7.14)$ & - \\
$\mathrm{D}(\mathrm{n}=11)$ & $1(9.09)$ & $1(9.09)$ & $1(5.09)$ & - & - \\
$\mathrm{E}(\mathrm{n}=7)$ & $1(14.29)$ & - & - & - & - \\
$\mathrm{F}(\mathrm{n}=5)$ & $1(20.00)$ & - & - & - & $1(20.00)$ \\
$\mathrm{G}(\mathrm{n}=5)$ & - & - & $1(20.00)$ & $1(20.00)$ & $1(20.00)$ \\
\hline
\end{tabular}

\section{Discussion}

The accessory pancreatic duct was found in $27.69 \%$ specimens, similar to as stated by Kamisawa ${ }^{1}$ and Sivak \& Sullivan ${ }^{17}$. However, it was lower than that of the findings of Mulholland $\&$ Simone $^{5}$ and Kamisawa et al. ${ }^{18}$.

Straight course of the accessory pancreatic duct was found in $50 \%$ specimens, while spindle course in $27.78 \%$ and cudgel course in $22.22 \%$ specimens were observed. The results were similar to that of Kamisawa ${ }^{1}$.

In this work, no communication between the common bile duct with accessory pancreatic duct was observed in $21.54 \%$ specimens. The results were similar to that of Mulholland \& Simeone ${ }^{5}$. Single and quadruple communications between the common bile duct with accessory pancreatic duct was present only in 1 specimen each in 2029 years age group. Triple communication between the common bile duct with main pancreatic duct was observed in 1 specimen each in group 20-29 years and30-39 years.

In this study, only in 11 specimens accessory pancreatic duct communicates with the main pancreatic duct, while no communication was found in 7 cases. Single communication was present in 2 cases each in group 20-29 years and 40-49, while double, triple and quadruple communications were present in 3 cases each in those groups. The results were lower than Mulholland \& Simeone ${ }^{5}$, Kleitsch ${ }^{8}$, Sivak \& Sullivan ${ }^{17}$ and Kamisawa et al. ${ }^{18}$. An accessory duct of Santorini is present in $85 \%$, while having communication with the main pancreatic duct in $33-90 \%$ of specimens was reported ${ }^{3,18}$.

A variable pattern was observed for the mode of opening of accessory pancreatic duct in the duodenum. 12 (66.67\%) accessory pancreatic ducts opened into the minor duodenal papilla, while $5(23.11 \%)$ into the major duodenal papilla and only $1(5.55 \%)$ accessory pancreatic duct opened into the $3^{\text {rd }}$ duodenal papilla. This result was similar to those of Mulholland \& Simeone ${ }^{5}$, MacCarty et al. ${ }^{15}$, and Sivak \& Sullivan ${ }^{17}$. However, it was not similar to the finding of Kleitsch ${ }^{8}$. It may be mentioned that in one instance in this study, after the minor papilla had been cannulated the accessory pancreatic duct was demonstrated to be the main drainage system for that pancreas, as supported by Bang et al. ${ }^{19}$.

\section{Conclusion}

Several variations were observed in accessory pancreatic ductal pattern in terms of their course, opening and communications. However, in the present study, no significant differences were 
evident in any parameter among the age groups. The results of the present study can be used as standard evidences in variational anatomy to correlate pancreaticobiliary pathophysiology in our population. Here, females were excluded due to less availability of the female cadaveric pancreas during study period.

\section{Author affiliations}

1. * Sunjida Shahriah, Associate Professor, Department of Anatomy, Z.H. Sikder Women's Medical College, Dhaka. Cell Phone: +8801983567207 .

2. Abu Sadat Mohammad Nurunnabi, Assistant Professor, Department of Anatomy, OSD, Directorate General of Health Services (DGHS), Dhaka.

3. Fatema Johora, Assistant Professor, Department of Anatomy, OSD, Directorate General of Health Services (DGHS), Dhaka.

4. Dilruba Siddiqua, Associate Professor, Department of Anatomy, Ibn Sina Medical College, Dhaka.

5. Shamim Ara, Professor \& Head, Department of Anatomy, Dhaka Medical College, Dhaka.

* For correspondence

\section{References}

1. Kamisawa T. Clinical significance of the minor duodenal papilla and accessory pancreatic duct. J Gastroenterol 2004; 39(7): 605-15.

2. Glass J, Mundy AR. Abdomen and pelvis. In: Standring S, Ellis H, Healy JC, Johnson D, Williams A, Collins P, et al. eds. Gray's anatomy: the anatomical basis of clinical practice. $39^{\text {th }}$ ed. Edinburgh: Elsevier Churchill Livingstone; 2005. p.1231-7.

3. Kamisawa T, Egawa N, Nakajima H, Sakaki N, Tsuruta K, Okamoto A. Clinical significance of the accessory pancreatic duct. Hepatogastroenterology 2003; 50(54): 2196-8.

4. Hruban RH, Wilentz RE. The pancreas. In: Kumar V, Abbas AK, Fausto N. eds. Robbins and Cotran pathologic basis of disease. $7^{\text {th }}$ ed. New Delhi: Saunders; 2004: p.939-53.

5. Mulholland MW, Simeone DM. Pancreas: anatomy and structural anomalies. In: Yamada T, Alpers DH, Laine L, Owyang C, Powell DW. eds. Textbook of Gastroenterology. $3^{\text {rd }}$ ed. Vol. 2. Philadelphia: Lippincott, Williams \& Wilkins; 1999: p.2107-20.

6. Burdick JS, Tompson ML. Anatomy, histology, embryology, and developmental anomalies of the pancreas. In: Feldman M, Friedman LS, Brandt LJ. eds. Sleisenger \& Fordtran's Gastrointestinal and liver disease. $8^{\text {th }}$ ed. Vol.1. Philadelphia: Saunders Elsevier; 2006: p.1173-87.

7. Skandalakis LJ, Rowe JS Jr, Gray SW, Skandalakis JE. Surgical embryology and anatomy of the pancreas. Surg Clin North Am 1993; 73(4): 66197.

8. Kleitsch WP. Anatomy of the pancreas: a study with special reference of the duct system. Arch Surg 1955; 71(6): 795-802.

9. Berman LG, Prior JT, Abramow SM, Ziegler DD. A study of the pancreatic duct system in man by use of vinyl acetate casts of postmortem preparations. Surg Gynecol Obstet 1960; 110: 391-403.

10. Silen W. Surgical anatomy of the pancreas. Surg Clin North Am 1964; 44: 1253.

11. Varley PF, Rohrmann CA Jr., Silvis SE, Vennes JA. The normal endoscopic pancreatogram. Radiology 1976; 118(2): 295-300.

12. Kune GA. Surgical anatomy of common bile duct. Arch Surg 1964; 89: 6995-7005.

13. Romanes GJ. Cunningham's manual of practical anatomy. $15^{\text {th }}$ ed. Vol. 2. New Delhi: Thomson Press (India); 2005: p.153-5.

14. Morton DA, Peterson KD, Albertine KH. Unit-II (Pancreas). Dissection guide for human anatomy. $2^{\text {nd }}$ ed. China: Churchill Livingstone; 2004: p.119.

15. MacCarty RL, Stephens DH, Brown AL Jr, Carlson HC. Retrograde pancreatography in autopsy specimen. Am J Roentgenol Radium Ther Nucl Med 1975; 123(2): 359-66.

16. Heiss FW, Shea JA. Association of pancreatitis and variant ductal anatomy dominant drainage of duct of Santorini. The Am J Gastroenterol 1978; 70: 158-62.

17. Sivak MV, Sullivan BH. Endoscopic retrograde pancreatography analysis of the normal pancreatogram. Am J Digest Dis 1976; 21(3): 263-9.

18. Kamisawa T, Tabata I, Tajima T, Tsushima K, Yoshida Y. Patency of the human accessory pancreatic duct as determined by dye-injection endoscopic retrograde pancreatography. Digestion 1997; 58(1): 78-82.

19. Bang S, Suh JH, Park BK, Park SW, Song SY, Chung JB. The relationship of anatomic variation of pancreatic ductal system and pancreaticobiliary diseases. Yonsei Med J 2006; 47(2): 243-8. 